\title{
Diagnostic laparoscopy in the evaluation of female factor infertility
}

\section{Ashok Kumar K., Priyanka Jogi Y., Bharathi Anjanappa*}

Department of Obstetrics and Gynaecology, ESIC MC PGIMSR, Rajajinagar, Bangalore, Karnataka, India

Received: 16 December 2016

Accepted: 21 December 2016

*Correspondence:

Dr. Bharathi Anjanappa,

E-mail: bharathiworld84@gmail.com

Copyright: () the author(s), publisher and licensee Medip Academy. This is an open-access article distributed under the terms of the Creative Commons Attribution Non-Commercial License, which permits unrestricted non-commercial use, distribution, and reproduction in any medium, provided the original work is properly cited.

\section{ABSTRACT}

Background: Infertility is a global problem, with more than 70 million couples suffering every year. In India 10-15\% of populations are suffering from infertility. All these people need accurate diagnosis and treatment. Among the many investigations available to evaluate the female partner of the infertile couples, laparoscopy is relatively recent and considered gold standard for pelvis evaluation. The objective of the study was to study the different causes of female factor infertility with diagnostic laparoscopy.

Methods: This is a prospective study done on 50 infertile females who attended infertility clinic of department of OBG, ESIC MC and PGIMSR, Rajajinagar, Bengaluru from September 2013 to 2015. Both primary and secondary infertility females were included in this study. These patients underwent diagnostic laparoscopy in premenstrual phase (7, 8, 9th day of menstrual cycle) after conducting thorough clinical and biochemical examinations.

Results: In the present study total 50 infertility cases were included. 41 cases had primary infertility and 9 cases had secondary infertility. Mean age was 29.88 years and mean duration of infertility was 5.9 years. Abnormal laparoscopic findings were detected in $41(82 \%)$ cases. Tubal factor was seen in $14(28 \%)$ cases, $11(22 \%)$ cases had endometriosis, $10(20 \%)$ cases had ovarian factor, $4(8 \%)$ cases had pelvic adhesions and 2(4\%) had fibroid uterus.

Conclusions: Tubal factor is the commonest cause for infertility followed by endometriosis and ovarian factor. Diagnostic laparoscopy is the gold standard procedure to assess tubal status. Laparoscopy has a better role than ultrasonography in diagnosing endometriosis and pelvic adhesions.

Keywords: Diagnostic laparoscopy, Primary infertility, Secondary infertility

\section{INTRODUCTION}

Parenthood is considered as the most desired goal in adulthood by the majority of world population. Couples who are not able to conceive face lot of social stigma and discrimination which has negative impact on their quality of life.

Infertility is defined as failure to conceive during one year of frequent unprotected intercourse. ${ }^{1}$ Worldwide more than 70 million couples suffer from infertility. ${ }^{2}$ WHO has recognized it as a major public health issue. In India $10-15 \%$ couples are infertile. According to WHO major causes for infertility are malnutrition, pelvic tuberculosis, and puerperal infections leading to tubal blockage. $^{3}$
Evaluation for infertility usually begins after one year of unprotected frequent intercourse. In some cases like female partner more than 35 yrs, evaluation can be started earlier because spontaneous abortion rates and chromosomal abnormality rates increase with maternal age.

Careful history taking and physical examination is a very important part of infertility evaluation. Success of treatment begins with the accurate diagnosis. In a limited resource country like India, we can't impose all the investigations of infertility on the infertile couples. We need to condense the list of investigations, which are unnecessarily routinely done on all the infertile patients. In such scenario, diagnostic laparoscopy plays a very important role. 
Laparoscopy is considered as gold standard to know the tubal status and also provides information about uterine, ovarian and pelvic pathology. Laparoscopy can also be used as therapeutic in cases of PCOD and pelvic adhesions. Laparoscopy not only increases pregnancy rate, it also modifies the line of treatment.

\section{METHODS}

An observational study was conducted at Department of OBG, ESIC MC and PGIMSR, Rajajinagar, Bangalore from September 2013 to September 2015. All the patients who presented with female factor infertility to OPD of Department of OBG ESIC MC and PGIMSR, Rajajinagar, Bangalore.

\section{Sample size: 50}

\section{Statistical analysis}

The data collected in this study was analysed by using descriptive statistics

\section{Inclusion criteria}

- All the women age between 20 to 40yrs who failed to conceive after 2 years of regular unprotected intercourse

- Normal semen analysis of husband

\section{Exclusion criteria}

- $\quad$ Age $>40 y r s$

- Patients with cardiovascular disease

- Patients with chronic respiratory disease

- Patients with generalized peritonitis

- Patients with intestinal obstruction

- Patients with active foci of tuberculosis

\section{Method of collection of data}

All the infertility patients who were selected for diagnostic laparoscopy procedure will undergo detailed clinical examination. Investigations like complete haemogram, random blood sugar, serological tests like HIV, HbsAg, VDRL, blood grouping and typing, urine microscopic examination, ECG, chest X-ray will be done. Patients were called for the procedure in the immediate post menstrual phase. $\left(7^{\text {th }}, 8^{\text {th }}\right.$ or $9^{\text {th }}$ day of the menstrual cycle). Informed written consent was taken.

Patients were subjected to laparoscopic procedure.

\section{Procedure}

After counselling and obtaining informed consent, the patient is subjected to general anaesthesia by endotracheal intubation. The patient was placed in the lithotomy position. Abdomen and the perineum were thoroughly cleansed and draped. The pneumoperitoneum was created by closed method using a veres needle at the umbilicus. The choice of the trocar and the telescope whether $5 \mathrm{~mm}$ or $10 \mathrm{~mm}$ depends upon the surgeon's preference. Any pathology of the uterus, the tubes and the ovaries were noted. Peritubal adhesions and kinks were also noted. Tubal patency was tested by using methylene blue, introduced by a cannula placed intravaginally.

Operative procedures like releasing of adhesions, kinks, ovarian drilling in cases of resistant PCOD, removal of ovarian cyst and endometriomas were done. At the end of the procedure the pelvic cavity is thoroughly lavaged with isotonic saline. The port sites were closed with the subcuticular sutures but the sheath in $10 \mathrm{~mm}$ is closed with delayed absorbable suture to prevent port site hernias. All the findings were noted. Patients were observed in the postoperative ward for 24 to $48 \mathrm{hrs}$ and discharged. Details of patients and findings obtained during the procedure were noted in the proforma Statistical analysis was done using descriptive analysis.

\section{RESULTS}

$48 \%$ of infertility patients were aged between 26-30 yrs and $32 \%$ of infertile patients were in the age group of 31 $35 \mathrm{yrs}$, and $20 \%$ were in the age group of 21-25 yrs. In primary infertility, most of them were in 26-30 yrs age group and in secondary infertility they were in 31-35 age group (Table 1). Mean age was 29.88 years.

Table 1: Age distribution.

\begin{tabular}{|lllll|}
\hline $\begin{array}{l}\text { Age } \\
\text { in } \\
\text { years }\end{array}$ & $\begin{array}{l}\text { Primary } \\
\text { infertility } \\
(\mathbf{n = 4 1 )}\end{array}$ & $\begin{array}{l}\text { Secondary } \\
\text { infertility } \\
(\mathbf{n = 0 9})\end{array}$ & $\begin{array}{l}\text { Total } \\
(\mathbf{N}=50)\end{array}$ & $\%$ \\
\hline $\begin{array}{l}\text { No. } \\
25\end{array}$ & No. & No. & $\%$ \\
\hline $\begin{array}{l}26- \\
30\end{array}$ & 21 & 3 & 10 & $(20)$ \\
\hline $\begin{array}{l}31- \\
35\end{array}$ & 12 & 4 & 24 & $(48)$ \\
\hline Total & 41 & 9 & 16 & $(32)$ \\
\hline
\end{tabular}

Table 2: Duration of infertility.

\begin{tabular}{|lllll|}
\hline $\begin{array}{l}\text { Duration } \\
\text { in years }\end{array}$ & $\begin{array}{l}\text { Primary } \\
\text { infertility } \\
(\mathbf{n = 4 1 )}\end{array}$ & $\begin{array}{l}\text { Secondary } \\
\text { infertility } \\
(\mathrm{n}=09)\end{array}$ & $\begin{array}{l}\text { Total } \\
(\mathrm{N}=50)\end{array}$ & $\%$ \\
\hline No. & No. & No. & $\%$ \\
\hline$<5$ & 14 & 1 & 15 & $(30)$ \\
\hline $5-10$ & 25 & 8 & 33 & $(66)$ \\
\hline$>10$ & 2 & 0 & 2 & $(4)$ \\
\hline Total & 41 & 9 & 50 & 100 \\
\hline
\end{tabular}

We studied 50 infertile women who underwent diagnostic laparoscopy. Out of 50 cases, 41(82\%) women had 
primary infertility and $9(18 \%)$ women had secondary infertility.

Table 3: Symptoms.

\begin{tabular}{|lllll|}
\hline Symptoms & $\begin{array}{l}\text { Primary } \\
\text { infertility } \\
(\mathbf{n = 4 1 )}\end{array}$ & $\begin{array}{l}\text { Secondary } \\
\text { infertility } \\
(\mathbf{n = 0 9})\end{array}$ & $\begin{array}{l}\text { Total } \\
(\mathbf{N}=50)\end{array}$ & $\%$ \\
\hline No. & No. & No. & $\%$ \\
\hline Asymptomatic & 27 & 3 & 30 & $(60)$ \\
\hline Dysmenorrhoea & 5 & 2 & 7 & $(14)$ \\
\hline $\begin{array}{l}\text { Chronic pelvic } \\
\text { pain }\end{array}$ & 4 & 1 & 5 & $(10)$ \\
\hline $\begin{array}{l}\text { Menstrual } \\
\text { problems }\end{array}$ & 5 & 3 & 8 & $(16)$ \\
\hline Total & 41 & 9 & 50 & 100 \\
\hline
\end{tabular}

Table 4: Ultrasonography findings.

\begin{tabular}{|c|c|c|c|c|}
\hline $\begin{array}{l}\text { USG } \\
\text { findings }\end{array}$ & $\begin{array}{l}\text { Primary } \\
\text { infertility } \\
(\mathrm{n}=41)\end{array}$ & $\begin{array}{l}\text { Secondary } \\
\text { infertility } \\
(n=09)\end{array}$ & \multicolumn{2}{|c|}{ Total $(\mathrm{n}=50)$} \\
\hline & No. & No. & No. & $\%$ \\
\hline Normal & 33 & 6 & 39 & (78) \\
\hline $\begin{array}{l}\text { Follicular } \\
\text { cyst }\end{array}$ & 2 & 2 & 4 & (8) \\
\hline $\begin{array}{l}\text { Polycystic } \\
\text { ovaries }\end{array}$ & 3 & 0 & 3 & (6) \\
\hline $\begin{array}{l}\text { Adnexal } \\
\text { mass }\end{array}$ & 3 & 1 & 4 & (8) \\
\hline Total & 41 & 9 & 50 & (100) \\
\hline
\end{tabular}

Table 5: Laparoscopic findings.

\begin{tabular}{|lllll|}
\hline Findings & $\begin{array}{l}\text { Primary } \\
\text { infertility } \\
(\mathbf{n = 4 1 )}\end{array}$ & $\begin{array}{l}\text { Secondary } \\
\text { infertility } \\
(\mathbf{n = 9})\end{array}$ & $\begin{array}{l}\text { Total } \\
(\mathbf{n = 5 0})\end{array}$ \\
\hline No. of cases & No. of cases & No. & $\%$ \\
\hline Normal & 9 & 0 & 09 & $(18)$ \\
\hline Abnormal & 32 & 9 & 41 & $(82)$ \\
\hline Total & 41 & 9 & 50 & 100 \\
\hline
\end{tabular}

Table 6: Causes of infertility.

\begin{tabular}{|lllll|}
\hline Causes & $\begin{array}{l}\text { Primary } \\
\text { infertility } \\
(\mathbf{n = 4 1 )}\end{array}$ & $\begin{array}{l}\text { Secondary } \\
\text { infertility } \\
(\mathbf{n = 0 9 )}\end{array}$ & $\begin{array}{l}\text { Total } \\
(\mathbf{n = 5 0 )}\end{array}$ & $\%$ \\
\hline Tubal factor & 10 & 4 & 14 & $(28)$ \\
\hline Endometriosis & 9 & 2 & 11 & $(22)$ \\
\hline Ovarian factor & 8 & 2 & 10 & $(20)$ \\
\hline Adhesions & 3 & 1 & 4 & $(8)$ \\
\hline Fibroid uterus & 2 & 0 & 2 & $(4)$ \\
\hline
\end{tabular}

Total of $15(30 \%)$ women had duration of infertility $<5$ years. $33(66 \%)$ of women had duration of infertility 5-10 years. Only $2(4 \%)$ women had duration of infertility $>10$ years. Mean duration of infertility was 5.9 yrs (Table 2).
Total of $30(60 \%)$ women were asymptomatic and 20 (40\%) were symptomatic. Among primary infertility patients, $65.8 \%$ were asymptomatic and $34.1 \%$ were symptomatic. Among secondary infertile patients, $33.3 \%$ were asymptomatic and $66.6 \%$ were symptomatic. Among symptomatic patients $14 \%$ had dysmenorrhoea, chronic pelvic pain in $10 \%$ of cases and menstrual problems in $16 \%$ of cases. Menstrual problems were in the form of oligomenorrhoea and irregular cycles (Table $3)$.

Normal pelvic USG findings were seen in $78 \%$ of cases, out of which 33 were in of primary infertility and 6 cases were in secondary infertility. Follicular cysts were seen in $8 \%$ of cases, out of which 2 were primary infertility and 2 were secondary infertility patients. Polycystic ovaries were seen in $6 \%$ of cases and all were in primary infertility patients. Adnexal mass was seen in $8 \%$ of cases, 3 in primary infertility and 1 in secondary infertility patients (Table 4).

Normal findings were seen in $9(18 \%)$ cases out of 50 cases. All were primary infertility cases. Abnormal finding were detected in 32 cases of primary infertility and all 9 cases of secondary infertility. Total 41 (82\%) cases had abnormal pelvic findings (Table 5). Tubal factor infertility was seen in $28 \%$ of cases, endometriosis in $22 \%$ of cases. Ovarian factor infertility was seen in $20 \%$ of cases. Adhesions were seen in $8 \%$ of cases. Fibroid uterus was seen in $4 \%$ of cases (Table 6).

Tubal factor infertility was seen in $28 \%$ cases of infertility. Out of which $8 \%$ had unilateral block, $18 \%$ had bilateral tubal block and $2 \%$ had hydrosalpinx. Out of 41 primary infertility cases we found tubal factor in 10 (20\%) cases. Out of 9 secondary infertility cases $4(8 \%)$ patients had tubal factor (Table 7).

Endometriosis was seen in $22 \%$ of cases Out of which, $4 \%$ was stage I, $8 \%$ was stage III, $12 \%$ was stage IV endometriosis respectively. Out of 41 primary infertility cases we found endometriosis in $9(18 \%)$ cases. 1 had stage I endometriosis, 3 had stage III endometriosis and 5 had stage IV endometriosis. Out of 9 secondary infertility cases $2(4 \%)$ patients had endometriosis. 1 patient had stage III endometriosis and another had stage IV endometriosis (Table 8).

Ovarian factor was seen in $20 \%$ of infertile patients, out of which $80 \%$ was seen in primary infertility patients and $20 \%$ in secondary infertile patients. $16 \%$ of primary infertility patients and $4 \%$ of secondary infertility patients had ovarian factor (Table 9).

Adhesions were seen in $8 \%$ of infertile patients and seedling fibroids in $4 \%$ of cases. In primary infertility cases, 3 had peritubal perifimbrial adhesions and 2 cases had seedling fibroids. In secondary infertility, 1 had peritubal adhesions (Table 10). 
Table 7: Tubal factor infertility.

\begin{tabular}{|c|c|c|c|c|}
\hline Findings & Primary infertility $(n=41)$ & Secondary infertility $(n=09)$ & Total $(n=50)$ & Findings \\
\hline & No. & No. & No. & \\
\hline U/l block & 3 & 1 & 4 & U/l block \\
\hline $\mathrm{B} / \mathrm{l}$ block & 6 & 3 & 9 & $\mathrm{~B} / \mathrm{l}$ block \\
\hline Hydrosalpinx & 1 & 0 & 1 & Hydrosalpinx \\
\hline
\end{tabular}

Table 8: Endometriosis.

\begin{tabular}{|lllll|}
\hline Findings & $\begin{array}{l}\text { Primary } \\
\text { infertility } \\
(\mathbf{n = 4 1 )}\end{array}$ & $\begin{array}{l}\text { Secondary } \\
\text { infertility } \\
(\mathbf{n}=\mathbf{0 9})\end{array}$ & Total \\
\hline No. & No. & No & $\%$ \\
\hline Stage I & 1 & 0 & 1 & $(2)$ \\
\hline Stage III & 3 & 1 & 4 & $(8)$ \\
\hline Stage IV & 5 & 1 & 6 & $(12)$ \\
\hline Total & 9 & 2 & 11 & $(22)$ \\
\hline
\end{tabular}

Table 9: Ovarian factor infertility.

\begin{tabular}{|lllll|}
\hline Findings & $\begin{array}{l}\text { Primary } \\
\text { infertility } \\
(\mathbf{n}=4 \mathbf{1})\end{array}$ & $\begin{array}{l}\text { Secondary } \\
\text { infertility } \\
(\mathbf{n}=09)\end{array}$ & \multicolumn{2}{c|}{ Total $(\mathrm{n}=50)$} \\
\hline No. & No. & No. & $\%$ \\
\hline $\begin{array}{l}\text { Simple } \\
\text { cyst }\end{array}$ & 1 & 1 & 2 & $(4)$ \\
\hline $\begin{array}{l}\text { Polycystic } \\
\text { ovaries }\end{array}$ & 6 & 1 & 7 & $(14)$ \\
\hline $\begin{array}{l}\text { Bald } \\
\text { ovaries }\end{array}$ & 1 & 0 & 1 & $(2)$ \\
\hline Total & 8 & 2 & 10 & $(20)$ \\
\hline
\end{tabular}

Table 10: Other laparoscopic findings.

\begin{tabular}{|lllll|}
\hline Findings & $\begin{array}{l}\text { Primary } \\
\text { infertility } \\
(\mathbf{n = 4 1 )}\end{array}$ & $\begin{array}{l}\text { Secondary } \\
\text { infertility } \\
(\mathbf{n = 0 9 )}\end{array}$ & \multicolumn{2}{l|}{ Total } \\
\hline No. & No & No & $\%$ \\
\hline Adhesions & 3 & 1 & 4 & $(8)$ \\
\hline Fibroid uterus & 2 & 0 & 2 & $(4)$ \\
\hline
\end{tabular}

Interventions were done in 15 cases. Ovarian drilling was done in 7 PCOS patients, adhesiolysis in 4 patients and endometriotic cyst excision in 4 patients (Table 11).

Table 11: Laparoscopic interventions.

\begin{tabular}{|lll|}
\hline & No. of cases & Percentage \\
\hline Ovarian drilling & 7 & $(14)$ \\
\hline Adhesiolysis & 4 & $(8)$ \\
\hline Cyst excision & 4 & $(8)$ \\
\hline Total & 15 & $(30)$ \\
\hline
\end{tabular}

\section{DISCUSSION}

Diagnostic laparoscopy has a very important role in the evaluation of causes and management in cases of infertility. It provides information regarding tubal status, pelvic adhesions, ovarian status, uterine pathology.

Mean age group in the present study was 29.88 yrs which was comparable to other studies conducted by Jayakrishnan et al (29.45 yrs) and Bonneau et al (32.2 yrs). ${ }^{4,5}$ Mean duration of infertility was 5.09 yrs in a study conducted by Jayakrishnan et al, 6.9 yrs in Naz et al study. In our study, mean duration of infertility was 5.98 yrs which was comparable to the above studies. ${ }^{4,6}$

Most of infertile patients may be asymptomatic without any complaints. In our study, $60 \%$ cases were asymptomatic, $14 \%$ had dysmenorrhoea, $10 \%$ had chronic pelvic pain, and $16 \%$ had menstrual problems. These results were comparable to study of $\mathrm{Naz}$ et al, in which $48 \%$ of cases were asymptomatic, $14 \%$ had dysmenorrhoea, $16 \%$ had chronic pelvic pain, and $22 \%$ had menstrual problems. ${ }^{6}$ Ultrasonography of abdomen and pelvis is one of the important basic investigations in the detection of pelvic pathology. In our study, normal findings were seen in $78 \%$ of cases, follicular cysts in $8 \%$ of cases, polycystic ovaries in $6 \%$ of cases and adnexal mass in $8 \%$ of cases. In a study of $\mathrm{Naz}$ et al, normal findings were seen in $80 \%$ of cases, follicular cysts in $5 \%$ of cases, polycystic ovaries in $6.2 \%$ of cases, adnexal mass in $2 \%$ cases and uterine abnormalities in $6.8 \%$ cases. In our study detection of adnexal mass was little high compared to $\mathrm{Naz}$ et al study. ${ }^{6}$ Diagnostic laparoscopy is the gold standard for diagnosing the pelvic pathology.

Table 12 shows laparoscopic findings in our study which was comparable to Tsuji et al and Mushtaq $\mathrm{R}$ et al. ${ }^{7,8}$ Laparoscopic findings were normal in $19.3 \%$ of cases and abnormal in $80.3 \%$ of cases in TSUJI et al study and similarly, $17.5 \%$ were normal and $82.5 \%$ were abnormal in Mushtaq F et al study, and $18 \%$ were normal and $82 \%$ were abnormal in the our study. ${ }^{7,8}$ The most common cause of infertility observed by laparoscopy in our study was tubal factor (28\%). The second common was endometriosis $(22 \%)$, followed by ovarian factor $(20 \%)$, adhesions (8\%) and fibroid uterus (4\%).

Tubal factor was detected in $26 \%$ of cases in Nausheen et al study, $26 \%$ in Agarwal $M$ et al study, 24\% in Goynumer $\mathrm{G}$ et al study. In our study tubal factor was 
attributed to $28 \%$ of cases which was comparable to the above studies. ${ }^{9-11}$

Table 12: Laparoscopic findings.

\begin{tabular}{|c|c|c|}
\hline Studies & Normal & Abnormal \\
\hline Tsuji et al ${ }^{7}$ & $19.3 \%$ & $80.7 \%$ \\
\hline Mushtaq R et $\mathrm{al}^{8}$ & $17.5 \%$ & $82.5 \%$ \\
\hline Present study & $18 \%$ & $82 \%$ \\
\hline
\end{tabular}

Endometriosis was the second most common cause of infertility in our study seen in $22 \%$ of cases which was comparable to the studies of DURAKER et al study (28.4\%) and Amogh et al study (32\%). ${ }^{12,13}$ Ovarian factor was detected in $18 \%$ of cases in Teleshere E et al study, $22 \%$ of cases in Chakraborti et al study and $20 \%$ of cases in our study. ${ }^{14,15}$ Adhesions were detected in $8 \%$ of cases in our study which was little higher than that detected in Jayakrishnan et al study (5.5\%) and Agarwal $\mathrm{M}$ et al study $(6 \%){ }^{4,10}$

\section{CONCLUSION}

Tubal factor is the commonest cause for infertility followed by endometriosis and ovarian factor. Diagnostic laparoscopy is the gold standard procedure to assess tubal status. Laparoscopy has better role than ultrasonography in diagnosing endometriosis and pelvic adhesions. Though it is an invasive procedure, complications are minimal with an experienced hand. Diagnostic laparoscopy is recommended in all the infertile women. Laparoscopy not only helps to find out different Causes of infertility, but it also guides us for further management.

\section{ACKNOWLEDGEMENTS}

We are all thankful for our OT staff, our patients, colleagues, postgraduate students for their contribution to the work. Special thanks to our Head of the department Dr. Renuka Ramaiah, our MS Dr. Rachita Biswas and Our Dean Dr. Rajeev Shetty. We are also thankful to the Almighty GOD for his blessings.

Funding: No funding sources Conflict of interest: None declared

Ethical approval: The study was approved by the Institutional Ethics Committee

\section{REFERENCES}

1. Speroff L, Glass RH, Kase NG Clinical Gynecologic Endocrinology and Infertility 8th edn. 2011:1137-90.
2. Omelet W, Cook I, Dyer S, Devroey P. Infertility and the provision of infertility medical services in developing countries. Hum Reprod Update. 2008;14:605-21.

3. Mehmood S. An audit of diagnostic laparoscopies for infertility. J Sur Pak. 2003;8:8.

4. Jayakrishnan K, Koshy AK, Raju R. Role of Laprohysteroscopy in women with normal pelvic imaging and failed ovulation stimulation with intrauterine insemination. J Hum Reprod Sci. 2010;3:20-4.

5. Bonneau C, Chandelles O, Sifer C, Poncelet C. Use of laparoscopy in unexplained infertility. Eur J Obstet Reprodu Biol. 2012;163:57-61.

6. Naz T, Hassan L. Laparoscopic evaluation in infertility. JCPSP. 2009;19:704.

7. Tsuji I, Ami K, Miyazaki A, Hujinami N, Hoshiai H. Benefit of diagnostic laparoscopy for patients with unexplained infertility and normal hysterosalpingography findings. Tohoku J Exp Med. 2009;219:39-42.

8. Mushtaq R, Mushtaq M, Iqbal S. Outcome of Laparoscopies for subfertility in military and combined Military Hospitals Rawalpindi. JSOGP. 2012;2:30-6.

9. Aziz N. Laparoscopic evaluation of female factors in infertility. J Coll Physicians Surg Pak. 2010;20(10):649-52.

10. Agarwal M, Anand NI. Laparoscopy in infertility. Int $\mathbf{J}$ Biol Med Res. 2014;5:3865-8.

11. Goynumer G , Yetim G, Gokcen O, Karaaslan I, Wetherilt L, Durukan B. Hysterosalpingography, Laparoscopy or Both in the Diagnosis of Tubal Disease in Infertility. World Journal of Laparoscopic Surgery. 2008;1:23-6.

12. Duraker R, Demer B, Dibaz B, Akkurt O, Kocale M. Comparisons of hysterosalpingography and laparoscopy results in the diagnosis of tubal occlusion. J Turk Soc Obstet Gynecol. 2011:8:40-3.

13. Chimote A, Saml S, Hariharan C, Agnik R. Laparoscopy and hysteroscopy in patients of infertility in a rural set up. Int $\mathrm{J}$ Reprod Contracept Obstet Gynecol. 2015;4:322-8.

14. Mboudou ET, Foumane P, Morfaw FL, Minkande JZ, Dohbit JS. Female infertility and laparoscopic surgery: A series of 415 operations at the Yaounde GynecoObstetric and Pediatric Hospital, Cameroon. OJOG. 2013;3:663-7.

15. Chakraborti DK, Jole SK. Diagnostic laparoscopy in gynecologic disorders. J Obst Gynaecol. 1990;40:262-5.

Cite this article as: Ashok Kumar K, Priyanka Jogi Y, Bharathi A. Diagnostic laparoscopy in the evaluation of female factor infertility. Int J Reprod Contracept Obstet Gynecol 2017;6:383-7. 